\title{
Immunogenicity of the Multi-Epitopic Recombinant Glycoproteins of Newcastle Disease Virus: Implications for the Serodiagnosis Applications
}

\author{
Mohammad Javad Motamedi ${ }^{1}$, Shahla Shahsavandi ${ }^{3}$, Jafar Amani ${ }^{2}$, Rouhollah Kazemi ${ }^{1}$, Somayeh \\ Takrim ${ }^{1}$, Mahyat Jafari ${ }^{1}$ and Ali-Hatef Salmanian ${ }^{1, *}$ \\ ${ }^{1}$ Department of Agricultural Biotechnology, National Institute of Genetic Engineering and Biotechnology (NIGEB), Tehran, Iran \\ ${ }^{2}$ Applied Microbiology Research Center, Baqiyatallah University of Medical Sciences, Tehran, Iran \\ ${ }^{3}$ Razi Vaccine and Serum Research Institute, Agricultural Research Education and Extension Organization, Karaj, Iran
}

${ }^{*}$ Corresponding author: Ali-Hatef Salmanian . Department of Agricultural Biotechnology, National Institute of Genetic Engineering and Biotechnology (NIGEB), Shahrake- Pajoohesh Blvd., 15th Km, Tehran-Karaj Highway, P.O. Box 14965-161, Tehran, Iran. Tel. + 982144787365 ; Fax: +98 2144787333. E-mail: salman@nigeb.ac.ir

Received: 16 Nov. 2016; $\quad$ Revised: 19 May. 2018; Accepted: 28 May. 2018; Published online: 12 Dec. 2018

\begin{abstract}
Background: Newcastle disease virus (NDV) is a dangerous viral disease, infecting a broad range of birds, and has a fatal effect on the poultry industries. The attachment and consequently fusion of the virus to the host cell membrane is directed by the two superficial glycoproteins, the hemagglutinin-neuraminidase $(\mathrm{HN})$ and the fusion $(\mathrm{F})$ which is considered as the important targets for the poultry immune response.

Objectives: The principal goal of this investigation was to realize the potential efficacy of the E. coli expression system for the production of the multi-epitopic $\mathrm{HN}$, and $\mathrm{F}$ proteins with respect to the ability for the stimulation of the immune system and production of the cross-reactive antibodies in mice.

Materials and Methods: The recombinant $\mathrm{HN}$ and $\mathrm{F}(\mathrm{rHN}, \mathrm{rF})$ have accumulated almost $40 \%$ of the total bacterial proteins. The presence of $\mathrm{rHN}$ and $\mathrm{rF}$ proteins recognized by the Western blotting with specific anti-HN, anti-F, anti-Newcastle B1, and anti-poly 6x His-tag antibodies. Furthermore, both $\mathrm{rHN}$ and $\mathrm{rF}$ have shown the specific reactivity against the Newcastle B1 antiserum as a standard strain.

Results: The ELISA analysis showed that the higher dilutions of the antibody against Newcastle B1 could react with the as least quantity as $100 \mathrm{ng}$ of the purified $\mathrm{rHN}$, and $\mathrm{rF}$. Cross-reactivity analysis of the sera from the mice immunized with Newcastle B1 in two time points indicated that the raise of anti-Newcastle B1, anti-HN and anti-F antibodies peaked at 28 days post immunization (dpi). Moreover, temporal variation in IgG titration between both time points was significant at 5\% probability level.

Conclusion: The results provided valuable information about the cross-reactivity patterns and biological activity of the multi-epitopic proteins compared to the NDV standard strain which was determined by the Western blotting and ELISA. Keywords: Affinity purification, Fusion, Hemagglutinin-neuraminidase, Immunization, Newcastle disease virus.
\end{abstract}

\section{Background}

Newcastle disease (ND) is a highly contagious viral disease in the domesticated birds, especially chicken, which causes a large economic loss in the poultry industry (1). Because of this impact, the World Organization for Animal Health (OIE) has considered this viral disease as the most significant disease of poultry (2). The causative agent of the infection is an RNA virus that belongs to the avian paramyxovirus serotype 1 (APMV-1), which shows variable pathogenicity and severity based on the strain's virulence (3). The infection of the host cells by the Newcastle disease virus (NDV) is accomplished through the interaction of the two major surface molecules, hemagglutinin-neuraminidase $(\mathrm{HN})$ and fusion glycoproteins (F) (4). The accurate mechanism

Copyright (C) 2018 The Author(s); Published by National Institute of Genetic Engineering and Biotechnology. This is an open access article, distributed under the terms of the Creative Commons Attribution-NonCommercial 4.0 International License (http://creativecommons.org/licenses/ by-nc/4.0/) which permits others to copy and redistribute material just in noncommercial usages, provided the original work is properly cited. 
of the viral membrane fusion and infection process has been investigated by many researchers in-depth (5-7). Briefly, the $\mathrm{HN}$ is responsible for attaching to the cell surface receptors including sialic acid and then $\mathrm{F}$ molecule triggers the fusion process. The insertion into the host cell membrane is processed by the $\mathrm{F}$ protein which plays a crucial role in the NDV pathogenicity (8). The immunological analysis has shown that both $\mathrm{HN}$ and $\mathrm{F}$ proteins could act as antigens in the virus structure and the neutralizing antibodies could be produced against these proteins in the infected animal $(9,10)$.

The live attenuated vaccines offer the possibility of the long-term protection, can influence the immune system to generate memory cells, and elicit good immunological responses. If a vaccine can evoke an incomplete immune response, it may be considered successful for preventing disease (11). Vaccines which employ live attenuated viruses are associated with some risks including the potential to induce disease, reversion to the virulence, as well as environmental spread. Also nowadays, most of the vaccines developed for the research application consist of the purified recombinant proteins or microbe's subunits (12). One of the major problems with this kind of vaccines is the selection of the correct antigen or antigens (13). The multimeric proteins which are connected by peptide linker could generate a broad range of immune responses and increase the immunogenicity of the recombinant proteins (14).

To achieve a more effective control of NDV, the early diagnosis is a critical point. Although the gold standard for the detection of NDV is hemagglutinin-inhibition (HI) test, in case of a high number of the serum samples, the ELISA test is the most reliable method. The immunodiagnostic methods such as ELISA have provided a high sensitivity and efficacy for the detection of NDV specific immune responses (15). For example, the expression of the recombinant ectodomain (nt 1421739) of the HN protein as inclusion bodies in the $E$. coli and its immunoblotting analyses have revealed the possibility of this recombinant protein as an antigen for the diagnosis of ND in the poultry (16). However, there is relatively limited information about the immunological properties of the recombinant surface glycoproteins of the NDV expressed in the E. coli system. There are a few reports about the successful expression and purification of NDV glycoproteins in the $E$. coli in which the recombinant $\mathrm{HN}$ was used as main the component in the ELISA based method (17) and purification of the immunogenic $\mathrm{F}$ protein that were studied elsewhere $(18,19)$.
An efficient production of the recombinant proteins in a highly purified and the well-characterized form could be achieved the through application of different expression systems such as E. coli (20). For example, numerous viral glycoproteins used in the immunological studies were produced in the E. coli such as: nonstructural protein-1 (NS1) from the influenza virus (21), NS1 protein of the dengue virus type 2 (22), the glycoprotein E2 of the swine fever virus (23), and glycoprotein gp160 of the Human Immunodeficiency Virus type 1 (HIV1) (24). Therefore, a simple and efficient method for antigens preparation could be used to evaluate vaccine efficiency and detection of the NDV infection.

\section{Objectives}

Multi-domain biological molecules which consist of several fused DNA fragments can present multiple functional properties resulting from each of its domains and subsequently induce a more effective response (25). Hence, in the present study, a chimeric HN-F construct which has already been designed by in silico assembling potential and conserved epitopic regions of the $\mathrm{HN}$ and $\mathrm{F}$ proteins of the NDV was used for further immunological analyses (26). To compare the expression efficiency, we attempted to express two multi-domain $\mathrm{HN}$ and $\mathrm{F}$ proteins individually in the $E$. coli. Furthermore, different factors such as solubility of the recombinant proteins after production in the heterologous host, purification process facility, immune system stimulation, production of the cross-reactive immune sera, and finally the utility of these specific immune sera to immunodiagnosis of the NDV were analyzed.

\section{Materials and Methods}

\subsection{Plasmids, Bacterial Strains, and Media}

PET-32a (+) plasmid (Novagen, USA), Rosetta-gami B (DE3) and DH5 $\alpha$ strains (Pasteur Institute of Iran) were used in this study. The Luria-Bertani (LB) broth or LB agar supplemented with the antibiotic (ampicillin, 100 $\mu$ g.mL $\mathrm{mL}^{-1}$, Sigma) was used for routine bacterial culture.

\subsection{Recombinant $H N$ and $F$ Plasmids Construction and Expression}

The single peptide construction consisted of the antigenic domains of $\mathrm{HN}$ and $\mathrm{F}$ glycoproteins was used in this study (26). Briefly, the epitopic amino acids from both HN (head and stalk domains) and F (HRA and HRB regions) proteins were selected and connected together using a linker consisting of several highly hydrophobic amino acids. The $h n(1000 \mathrm{bp})$ and $f(852$ 
Motamedi MJ et al.

Table 1. Primer sequences used in this experiment

\begin{tabular}{|c|c|c|c|}
\hline Primer & Sequence $\left(5^{\prime}-3^{\prime}\right)$ & Restriction site & $\begin{array}{l}\text { PCR product (length; } \\
\text { bp) }\end{array}$ \\
\hline $\mathrm{HNf}$ & TCTAAGGATCCACACCACTGGGTTGCGACA & BamHI & \multirow{2}{*}{ hn (999) } \\
\hline $\mathrm{HNr}$ & CTTGCTCTCGAGTTATTCTGTCTTCAGGAGTGCCA & XhoI & \\
\hline Ff & TGTTCGGATCCAAAAACATCTCCATCCAAGA & BamHI & \multirow{2}{*}{$f(852)$} \\
\hline $\mathrm{Fr}$ & CTATTGCTCGAGTTATGAATCGTACAGGATTGGGT & XhoI & \\
\hline
\end{tabular}

bp) synthetic gene were amplified from the synthetic HN-F gene (Gene Bank accession no. JX442483) using the specific primers (Table 1). For further cloning procedure, the BamHI and XhoI restriction sites were introduced at the $5^{\prime}$ terminus of the each forward and reverse primers, respectively. PCR amplification using DNA polymerase was performed for 30 cycles of $1 \mathrm{~min}$ at $94{ }^{\circ} \mathrm{C}, 1 \mathrm{~min}$ at $60{ }^{\circ} \mathrm{C}$, and $2 \mathrm{~min}$ at $72{ }^{\circ} \mathrm{C}$ followed by the final extension at $72{ }^{\circ} \mathrm{C}$ for $10 \mathrm{~min}$. The PCR products were cloned into the expression vector pET-32a $(+)$, downstream of the $\mathrm{T} 7$ promoter, the thioredoxin (Trx-tag), and the His-tag sequences. The construct was transformed into the $E$. coli Rosettagami B (DE3) competent cell. The presence of the each gene in the expression host was verified by the PCR, digestion with the restriction endonucleases, and finally by sequencing.

\subsection{Expression and Purification of the Recombinant Proteins}

E. coli Rosetta-gami strain carrying the recombinant plasmid of pET-32a: HN and pET-32a: F were grown at $37^{\circ} \mathrm{C}$ to an $\mathrm{OD}_{600}$ of 0.6 . The culture was induced by $1 \mathrm{mM}$ isopropyl- $\beta$-D-galactopyranoside (IPTG, Sigma) and incubated at $37{ }^{\circ} \mathrm{C}$ for further 4 hours. Cells were harvested by centrifugation $(5000 \times \mathrm{g}, 10$ min, $\left.25^{\circ} \mathrm{C}\right)$ and resuspended in the lysis buffer $(100$ $\mathrm{mM} \mathrm{NaH} \mathrm{PO}_{4}, 10 \mathrm{mM}$ Tris-Cl, $8 \mathrm{M}$ urea, $\mathrm{pH}$ 8.0). After sonication (6 times for 10 second with high power), the lysate was centrifuged (15 $\mathrm{min}, 10000 \times \mathrm{g}$, $4{ }^{\circ} \mathrm{C}$ ) and the supernatant was applied on a Ni-NTA chromatography column (Qiagen, USA). The two recombinant proteins appeared in inclusion bodies after analysis on 12\% SDS-PAGE. The denaturing condition was used for purification of the recombinant $\mathrm{HN}$ and $\mathrm{F}$. The purification was performed based on the procedure described by the manufacturer with minor changes. The lysis buffer was used for equilibration of the Nickel-nitrilotriacetic acid (Ni-NTA) column. The protein solution was loaded precisely onto the column (flow rate of $0.5 \mathrm{~mL} \cdot \mathrm{min}^{-1}$ ). The impurity was removed two times by washing the column with the washing buffer $\left(100 \mathrm{mM} \mathrm{NaH}{ }_{2} \mathrm{PO}_{4}, 10 \mathrm{mM}\right.$ Tris$\mathrm{Cl}, 8 \mathrm{M}$ urea) with different $\mathrm{pH}$ (i.e., $\mathrm{pH}$ : 6.3 and $\mathrm{pH}$ 5.9) for $\mathrm{HN}$ and $(\mathrm{pH} 7.0$ and $\mathrm{pH}$ 6.3) for $\mathrm{F}$ proteins, respectively. The recombinant proteins were eluted with elution buffer $\left(100 \mathrm{mM} \mathrm{NaH} \mathrm{PO}_{4}, 10 \mathrm{mM}\right.$ Tris$\mathrm{Cl}, 8 \mathrm{M}$ urea) at $\mathrm{pH} 4.5$. The protein concentration was determined by the Bradford method with BSA (bovine serum albumin) as a standard. Finally, a stepwise dialysis was performed until urea reached a concentration of zero $\mathrm{M}$ and then repeated two times against PBS buffer (pH: 7.4) containing 10\% glycerol and subsequently without glycerol to prevent protein aggregation.

\subsection{Animal Model Immunization}

To determine the antigenicity of the recombinant $\mathrm{HN}$ and F proteins, twenty Balb/c mice (female, 6-8-weeks-old, Pasteur Institute, Tehran, Iran) were randomly divided into four groups (A to D) and acclimatized for 1 week. Group $\mathrm{A}$ and $\mathrm{B}$ were respectively inoculated with $15 \mu \mathrm{g}$ of the purified $\mathrm{rHN}$ and $\mathrm{rF}$ subcutaneously into the quadriceps muscle using complete Freund's adjuvant (CFA, Sigma, USA). The group $\mathrm{C}$ was immunized with a commercial vaccine (B1 strain) as the positive control (a generous gift from Dr. M. M. Ebrahimi from Razi Vaccine and Serum Research Institute, Karaj, Iran) and the last group (D) was immunized with PBS plus CFA as the negative control. The immunization continued by two booster doses, each $10 \mu \mathrm{g}$ of the recombinant antigens with the incomplete Freund's adjuvant (IFA, Sigma, USA) and finally one booster $(2 \mu \mathrm{g})$ via intraperitoneal route at an interval of two weeks. The immune serum was prepared from the blood sample of each mice group. For serum preparation, the animal's blood was transferred into vials and allowed to clot for $30 \mathrm{~min}$, the serum was collected by centrifugation, and was kept frozen at $-70{ }^{\circ} \mathrm{C}$ until use. The serum samples of each mice group were prepared and then pooled for the immunological analyses. 


\subsection{Western Blotting}

The recombinant proteins ( $\mathrm{rHN}$ and $\mathrm{rF}$ ) were separated by $12 \%$ SDS-PAGE and transferred onto PVDF membrane (Roche, Germany). The membrane blocking was done with non-fat skim milk $(5 \%)$ in TBS buffer (50 mM Tris-Cl, $150 \mathrm{mM} \mathrm{NaCl}, \mathrm{pH}$ 7.5) containing $0.05 \%$ Tween 20 at $37{ }^{\circ} \mathrm{C}$ for 2 hours. The membrane was further incubated with antiserum against $\mathrm{rHN}$ and $\mathrm{rF}$ from the immunized mice (1:1000 dilution) and hyperimmune serum specific to Newcastle B1 strain (1:500), separately. The HRP-conjugated goat antimouse IgG (1:2000; Sigma, Germany) was used as the secondary antibody. Finally, the membrane was soaked in 3, 3'-Diaminobenzidine tablet (DAB Reagents; Sigma) for signal development. This procedure was repeated with HRP-conjugated anti-His tag (1:500, Roche) for both recombinant $\mathrm{HN}$ and $\mathrm{F}$ proteins. Furthermore, to verify the cross-reactivity of the immune sera, the Newcastle B1 strain were blotted onto PVDF and incubated with antisera from rHN and rF immunized mice.

\subsection{ELISA Analysis of the Recombinant Proteins}

The sera from the immunized mice were assayed for the presence of specific antibody by ELISA test. The purified $\mathrm{rHN}$ and $\mathrm{rF}$ (500 ng per well) in 100 $\mu \mathrm{L}$ bicarbonate buffer $\left(15 \mathrm{mM} \mathrm{Na}_{2} \mathrm{CO}_{3}\right.$ and $35 \mathrm{mM}$ $\mathrm{NaHCO}_{3}$ ) were used to coat Maxisorb plates (Nunc, Denmark) overnight at $4{ }^{\circ} \mathrm{C}$. The wells were blocked for additional two hours at $37^{\circ} \mathrm{C}$ by covering the well with $200 \mu \mathrm{L}$ of $5 \%(\mathrm{w} / \mathrm{v})$ non-fat skim milk in PBST (PBS containing $0.05 \%$ Tween-20). After washing with PBST ( 3 times), the wells were exposed to the diluted immunized serum in a triplicate manner at $100 \mu \mathrm{L}$ per well for 1 hour at $37^{\circ} \mathrm{C}$. The bound antibodies were detected with the goat anti-mouse $\mathrm{IgG}$ conjugated with HRP (Sigma, Germany) in a 1:5000 dilution for 1 hour and washed with PBST (3 times). The reaction was developed with O-phenylenediamine (OPD) as a substrate for HRP (Sigma, Germany) for $15 \mathrm{~min}$ at ambient temperature and in a dark place. Sulfuric acid $(2.5 \mathrm{M})$ was added to the reaction and the absorbance in each well was measured at $492 \mathrm{~nm}$.

\subsection{Statistical Assessment}

SPSS 16.0 was used for all statistical analyses. The statistical significance was considered for the p-value less than $0.05(p<0.05)$. The mean differences were studied by Duncan's multiple range test.

\section{Results}

\subsection{Construction of the Expression Plasmids}

The specific primers were designed to amplify $h n$ and $f$ fragments from the pUC57-hnf plasmid as a template. The PCR product of $h n(\sim 1000 \mathrm{bp})$ and $f(\sim 850 \mathrm{bp})$ was digested (BamHI / XhoI) and cloned in pET32a which was digested with the same enzymes. The proper cloning procedure was confirmed by colony PCR and restriction enzyme digestion (Fig. 1A, Fig. 1B and Fig. 1C). The identity of the $h n$ and $f$ genes in the recombinant plasmids construct was confirmed by the sequencing (data not shown).

\subsection{The Expression and Purification of the Recombinant Proteins}

The expression of recombinant proteins was analyzed on $12 \%$ SDS-PAGE and the two fragment: $\mathrm{rHN}$ (54 $\mathrm{kDa})$ and $\mathrm{rF}(49 \mathrm{kDa})$ in the fusion with Trx-tag and $6 \mathrm{x}$ His-tag (N-terminal) were detected (Fig. 2A and Fig. 2B). The expressed recombinant proteins produced as inclusion bodies (IB) (Fig. 2C and Fig. 2D) were subsequently solubilized using $8 \mathrm{M}$ (Fig. 3A). The rHN

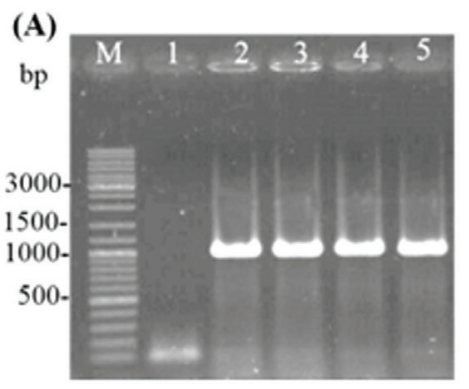

(B)

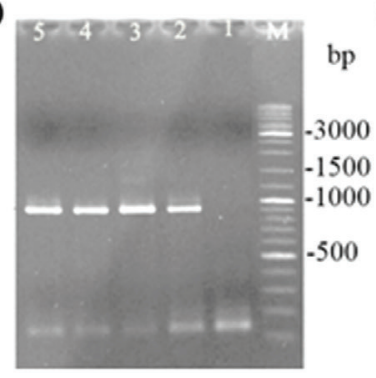

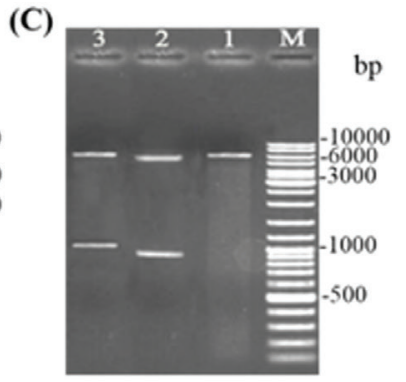

Figure 1. Confirmation of (A) $h n(1000 \mathrm{bp})$ and (B) $f(852 \mathrm{bp})$ genes cloning by PCR and digestion. In (A) and (B), lane 1 corresponds to the non-recombinant plasmid and lane 2 the positive control. (C) The recombinant plasmids were digested with $\mathrm{BamHI} / X h o \mathrm{I}$ restriction enzymes, lane 1: pET32a (+) (5900 bp), lane 2: pET-32a $(+) / f(852 \mathrm{bp})$, lane 3: pET-32a $(+) / h n(1000 \mathrm{bp})$, and M: DNA Ladder Mix (Thermo). 


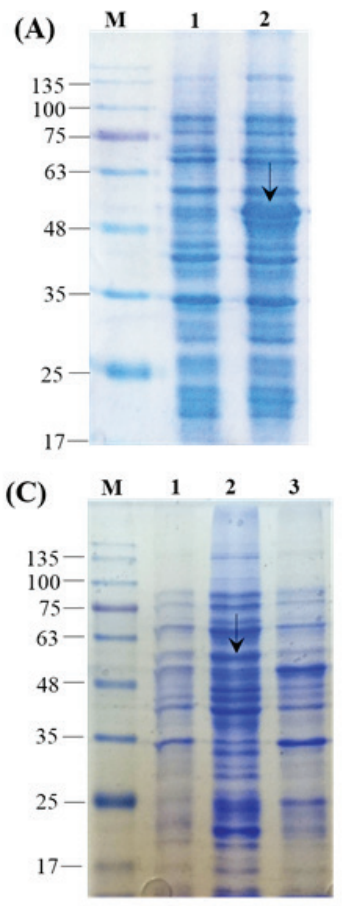

(B)

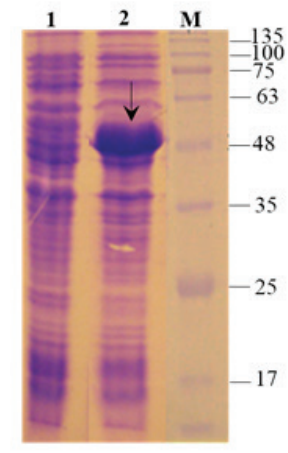

(D)

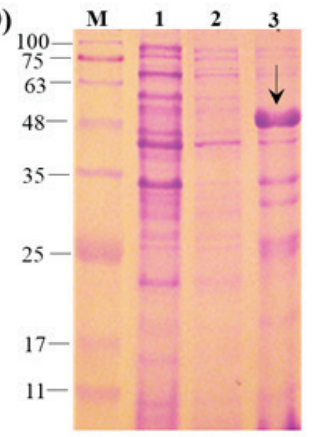

Figure 2. (A) SDS-PAGE analysis of the total bacterial proteins containing pET32a- $h n$ (lane 2, 54 kDa), (B) pET32a- $f$ (lane 2, 49 $\mathrm{kDa}$ ); in both gels lane 1 corresponds to before induction condition. (C) Determination of target proteins' solubility for $\mathrm{rHN}$ (lane 2: insoluble, lane 3: soluble fractions) and (D) $\mathrm{rF}$ (lane 2: soluble, lane 3: insoluble fractions), and lane 1 is the non-induced control. M: protein molecular weight marker (KD).

and $\mathrm{rF}$ were produced as approximately $40 \%$ of the total bacterial proteins and the highest detectable level of the purified $\mathrm{rHN}$ and $\mathrm{rF}$ were calculated up to 0.37 and $0.45 \mathrm{mg} \cdot \mathrm{mL}^{-1}$, respectively.

\subsection{Immunoblotting of the Recombinant Proteins}

The authenticity of the recombinant $\mathrm{HN}(54 \mathrm{kDa})$ and $\mathrm{F}(49 \mathrm{kDa})$ proteins were confirmed by using anti-poly His-tag antibody (Fig. 3B). Moreover, the presence of $\mathrm{HN}$ and $\mathrm{F}$ recombinant proteins were recognized by the specific anti-HN, anti-F, and anti-Newcastle B1 antibodies (Fig. 3C and Fig. 3D; lane 2). The antiNewcastle B1 antibody which was produced in the immunized mice was used to characterize the purified $\mathrm{rHN}$ and $\mathrm{rF}$ proteins (Fig. 3C and Fig. 3D; lane 3). It was suggested that the two epitopic proteins possess antigenicity and the specific reactivity with the Newcastle B1 strain. The bands of approximate $49 \mathrm{kDa}$ and $54 \mathrm{kDa}$ (Fig. 3C and Fig. 3D; lane 4) clearly showed the robust and specific immune reaction between the selected antigens and a standard B1 virus strain. In contrast, there was no reactivity in the negative control (Fig. 3C and Fig. 3D; lane 1).

\subsection{ELISA and Cross-Reactivity Analysis}

The ELISA assay was used to determine the quantity of the specific IgG antibodies against $\mathrm{HN}$ and $\mathrm{F}$ purified proteins. The specific IgG antibodies against $\mathrm{HN}$ and $F$ fragments were detected after the first immunization in the sera of the immunized mice and were increased significantly after the second booster (Fig. 4A and Fig. 4B). There was a significant difference $(p<0.05)$ in the antibody titers between $\mathrm{rHN}$ and $\mathrm{rF}$ in the first injection. As previously mentioned, Western blot data indicated that the serum of the immunized animal with the Newcastle B1 strain could detect $\mathrm{rHN}$ and $\mathrm{rF}$ proteins and vice versa. The ELISA results confirmed these findings and showed that the higher dilutions of the anti-Newcastle B1 antibody reacted with the very low amount (i.e., $100 \mathrm{ng}$ ) of the purified $\mathrm{rHN}$ and $\mathrm{rF}$. Despite some differences in endpoint titers of the antibodies, they were not statistically significant $(p<$ 0.05, Fig. 4C).

To evaluate the cross-reactivity of the recombinant
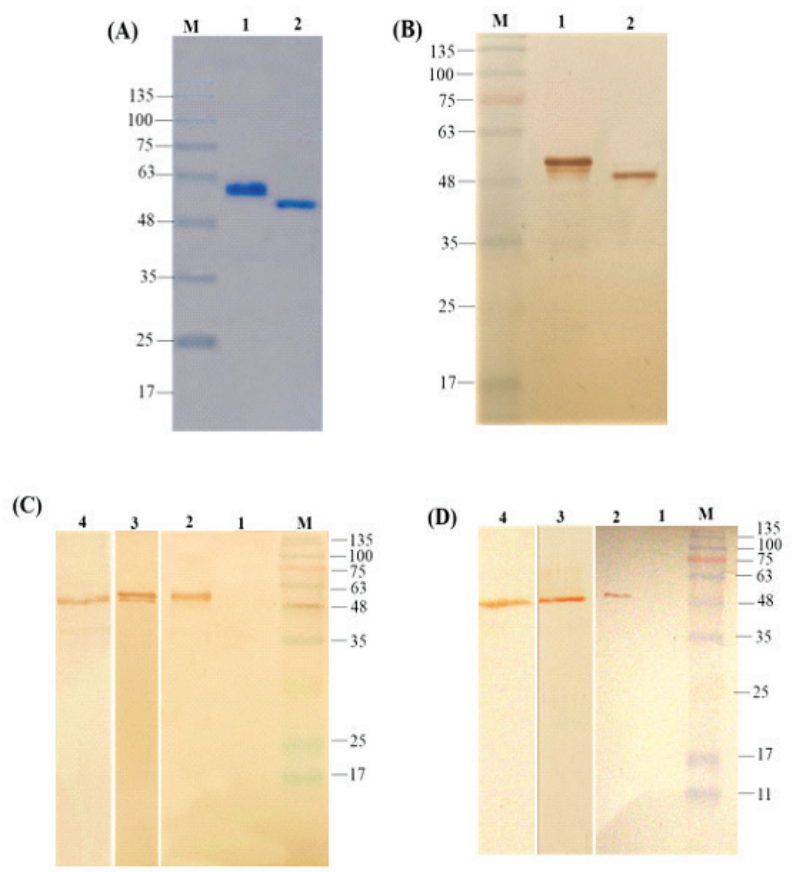

Figure 3. (A) SDS-PAGE analysis of the purified rHN (lane 1) and $\mathrm{rF}$ (lane 2) under denaturing conditions. (B) Western blotting of the purified recombinant $\mathrm{rHN}$ (lane 1) and $\mathrm{rF}$ (lane 2) with anti-His tag antibody. (C) and (D) Western blot analysis of the rHN and $\mathrm{rF}$ with specific anti-HN, anti-F (lane 2), and anti-Newcastle B1 (lane 3) antibodies, respectively; lane 4 corresponds to the cross-reactivity analyses of the Newcastle B1 virus strain detected by specific anti$\mathrm{HN}$ and anti-F antibodies, respectively. Lane 1 in (C) and (D) are the negative control non-recombinant pET32a. M: protein molecular weight marker (KD). 

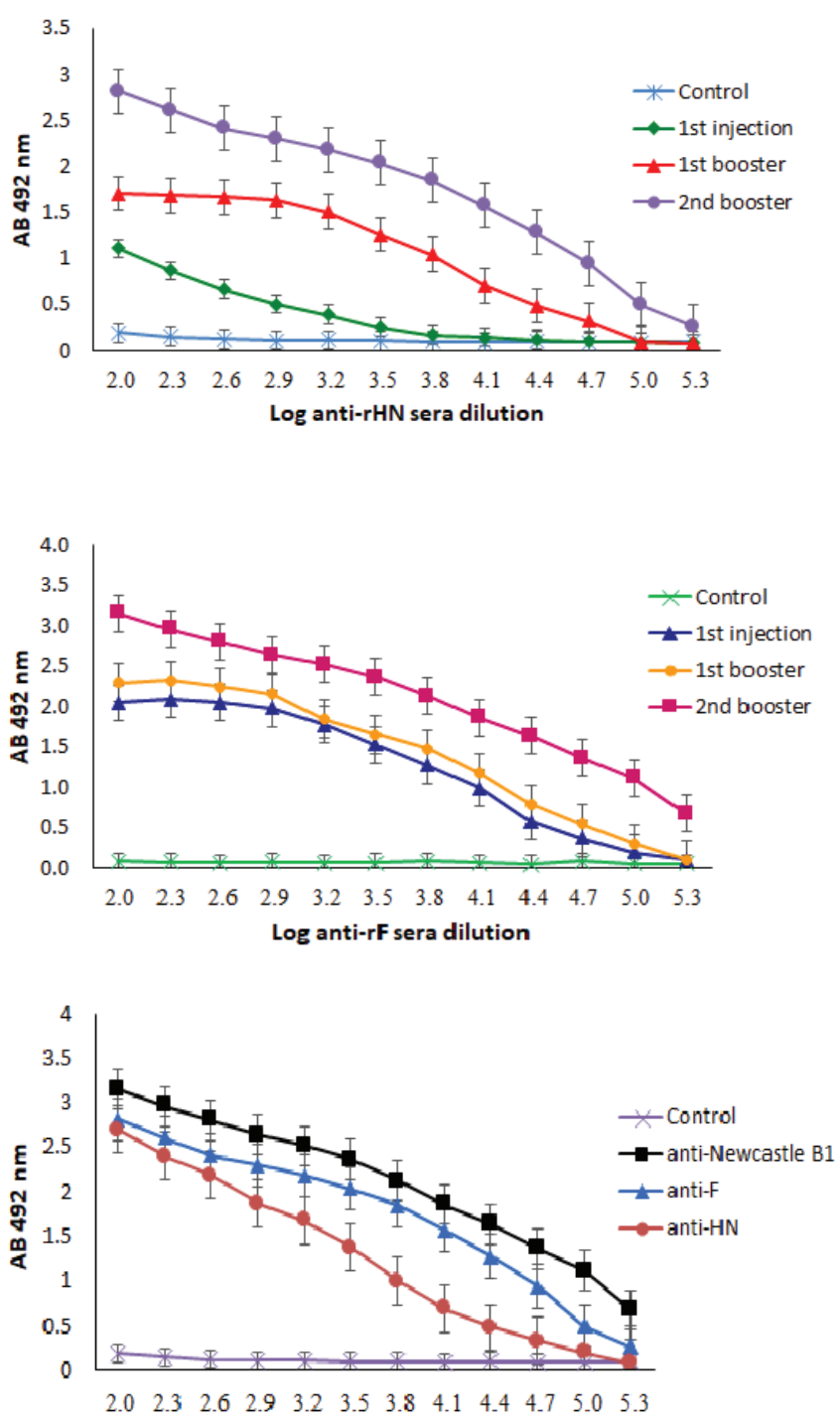

Log anti Newcastle B1 sera dilution

Figure 4. The $\mathrm{IgG}$ response to $\mathrm{rHN}(\mathbf{A})$ and $\mathrm{rF}(\mathbf{B})$ in the immunized mice sera. (C) Titration of the sera from Newcastle B1 mice immunized with $\mathrm{rHN}, \mathrm{rF}$, and Newcastle B1.

proteins ( $\mathrm{rHN}$ and $\mathrm{rF}$ ), the sera from mice immunized with the Newcastle B1 were collected at 14 and 28 days post first immunization (dpi), and ELISA assay was conducted to determine the specific antibody titers (Fig. 5A and Fig. 5B). Titration of the anti-HN and anti-F antibodies was monitored and compared with the anti-Newcastle virus B1 strain. The titer of the antiNewcastle B1, anti-HN, and anti-F reached at the peak level after 28 dpi and temporal variation between alltime points were significant $(p<0.05)$. Sera from the mice immunized with the Newcastle B1 could crossreact with the pure $\mathrm{rHN}$ and $\mathrm{rF}$, respectively (Fig. 5A
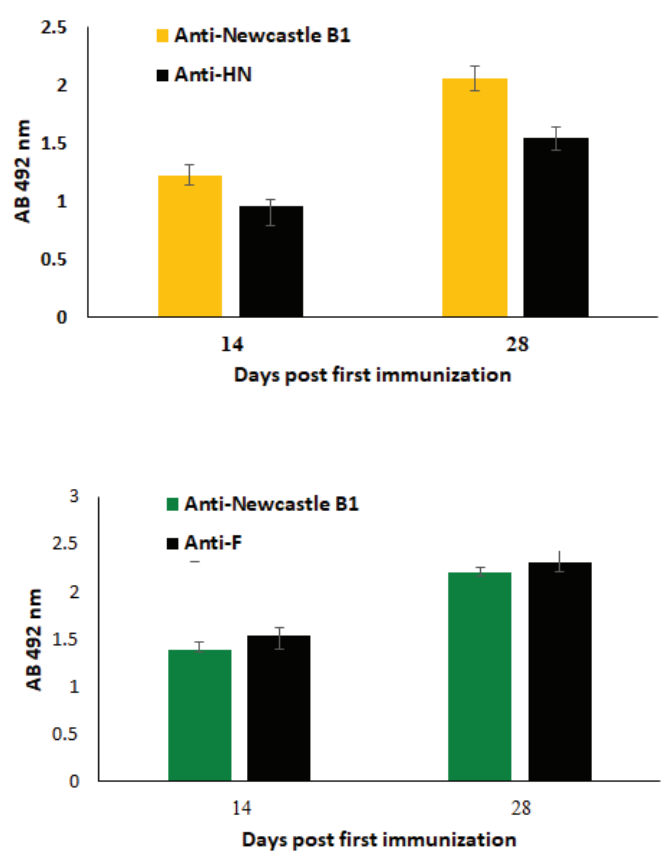

Figure 5. Estimation of serum antibody response and crossreactivity analyses of the antibodies from the immunized mice versus recombinant purified proteins $\mathrm{rHN}(\mathbf{A})$ and $\mathrm{rF}$ (B) by ELISA at various days post-first injection. The comparison between samples was conducted using the Duncan test at the 5\% level, and the error bars are $\pm 1 \mathrm{SD}$. Values within a column followed by different letters are significantly different $(p<0.05)$.

and Fig. 5B). The antibody titers specific to both $\mathrm{rHN}$ and $\mathrm{rF}$ were not detected in the control group injected with PBS (data not shown).

\section{Discussion}

The production of the viral antigens through recombinant technology has provided us with an opportunity to use these protective regions from the virus structure as safe and non-replicating immunogens. The recombinant $\mathrm{ND}$ vaccines harboring the $\mathrm{HN}$ and F proteins' genes have been constructed using various expression systems mainly baculovirus (27), cytomegalovirus (28), and plants systems (29). The protection against the NDV has been demonstrated by using the F, HN, or both proteins produced in the viral vectors as successful vaccines (30). In this study, we have shown that recombinant multi-epitopic regions of $\mathrm{HN}$ and $\mathrm{F}$ glycoproteins, instead of the whole molecule, can be produced efficiently in the E. coli as host cells. Our findings showed that recombinant proteins of the multiepitopic HN and F of the NDV could be detected by the sera from the immunized mice with the Newcastle 
B1 virus strain and vice versa. Despite this finding, a detailed study on the combination of these two antigens for the development of serological tests has become necessary.

In order to overcome the problem of inclusion body production in the expression of the recombinant proteins, HN and F, pET32a vector was used. This vector encodes 109 aa trxA (Trx-tag) domain at the 5 '-end of its multiple cloning sites immediately upstream S-Tag (15 aa) sequence that theoretically has to improve the solubilization of the target proteins. However, the fusion of the $\mathrm{HN}$ and $\mathrm{F}$ polypeptide to the N-terminus of Trx protein did not lead to the expression of $\mathrm{rHN}$ and $\mathrm{rF}$ in the soluble fraction of the bacterial cell lysate. It seems that the insolubility of the chimeric $\mathrm{HN}$ and $\mathrm{F}$ could be attributed to the hydrophobic nature of several strong hydrophobic residues in the different regions of the proteins, thereby making them difficult to solubilized, isolate or purify (31). It was proven that the degree of the soluble expression versus that of insoluble protein in the fusion constructs is dependent on the nature of the target protein (32). In fact, recombinant proteins which expressed in the E. coli cytoplasm is partially insoluble due to hydrophobic residues which distributed on the surface of the proteins (33). Other studies have reported the soluble expression of $\mathrm{HN}$ or $\mathrm{F}$ in $E$. coli host in which the vectors with a fusion partner such as Trx and NusA have been used $(16,17)$. It was revealed that the expression of subunits of the heteromultimeric proteins in the soluble form sometimes results in their aggregation as the inclusion body in absence of a proper fusion tag (33). In a similar research, Wong et al. (16) have reported that the insoluble rHN protein elicits a more rapid and stronger immune response in compression to the soluble NusA HN protein.

It was demonstrated that the insoluble protein aggregates in form of inclusion bodies have an advantage in the protein purification process since they can be harvested from the lysed cells using a moderatespeed centrifugation and also be protected against the proteolytic degradation by the host cell proteases (32). Moreover, the concentration of the solubilizing agent slowly decreases during dialysis which allows the protein to refold optimally (34). The minimal aggregation of the purified recombinant $\mathrm{HN}$ and $\mathrm{F}$ proteins was achieved by the step-wise decrease in the urea concentration $(8 \mathrm{M}$ to $0 \mathrm{M})$ in order to ensure a proper solubilization and may also refold of the proteins to their native conformation.

It was found that the $\mathrm{HN}$ and $\mathrm{F}$ proteins could stimulate neutralizing antibody responses and was considered as effective and protective antigens (35). Studies using monoclonal antibodies have revealed the presence of various epitopes within the HN (36) and F protein (37). Since the goal of this study was to use these proteins in the immunodetection, the existence of the antibody against $\mathrm{HN}$ and $\mathrm{F}$ antigens in the serum of the mice compared to that of the control group was evaluated by the Western blot to confirm antigenic characteristic of the recombinant proteins. Whereas blotting with the serum of immunized mice has had always background due to general antibodies against $E$. coli proteins, it is better the results of Western blotting first become subject of comparison before and after induction for the presence or absence of the desired band (Fig. 4C and Fig. 4D). Moreover, the cross-reactivity of the multi-epitopic recombinant protein antigens with serum samples from mice immunized with B1 strain of NDV was analyzed.

Furthermore, Western blotting analysis could only show the reaction of the continuous epitopes and the corresponding antibodies because conformational epitopes denatured in the presence of SDS detergent (38). The immunoblotting results showed an appropriate interaction between all immunized mice sera raised against $\mathrm{rHN}$ and $\mathrm{rF}$ proteins. In this regard, several studies have reported the nature of the epitopes present on the immune-blotted $\mathrm{HN}$ and $\mathrm{F}$ proteins in which the continuous epitopes were able to regenerate after denaturation in SDS-PAGE (37, 39-41). Furthermore, E. coli cells lack metabolic pathways for glycosylation and are unable to add oligosaccharide chain to the recombinant proteins (20). Therefore, binding of the antibodies to the recombinant $\mathrm{HN}$ and $\mathrm{F}$ proteins was limited to the involvement of the linear epitopes devoid of carbohydrates.

Mice administrated with the $\mathrm{rF}$ protein showed significant antibody titers two weeks after the first injection. The antibody titers had a constant trend even after the first booster of the rF protein $(\log =2.04-2.28)$. After the second injection, the titers went up steadily to $\log =2.84$ (Fig. 5B). In contrast, mice injected with the recombinant $\mathrm{HN}$ protein did not show an increase in their response by the production of antibody until the booster injection was given. The titer of antibody was increased slightly from $\log 10: 1.10-1.70$ after the first injection of the rHN protein and ultimately reached a significant level of $\log 10: 2.31$ (Fig. 5A). The recombinant $\mathrm{HN}$ and $\mathrm{F}$ proteins in the inclusion bodies were in the state of protein aggregates which could increase the likelihood of the effective T-cell epitope response and engage the antigen-processing cells (42). Analysis of cross-reactive antibodies 
against the recombinant purified proteins in the mice has indicated that $\mathrm{HN}$ and $\mathrm{F}$ proteins could elicit the immune response against the both molecules. Results of the experiment showed that the mutiepitopic recombinant $\mathrm{HN}$ and $\mathrm{F}$ antigens expressed in the E. coli could elicit a sufficient rise of antibody in the immunized mice for detection by ELISA as well as standard Newcastle vaccine which composed of the whole structural NDV proteins. On the other hand, the commercial strains that are currently being used for detection of NDV induce a high amount of antibodies which may not directly produce against $\mathrm{HN}$ or $\mathrm{F}$ antigens, because NDV structural proteins like nucleocapsid protein (NP) are also associated with the high immunogenicity properties, as well $(17,43)$.

Despite an equal amount of these recombinant proteins, the antibody responses to $\mathrm{F}$ and $\mathrm{HN}$ were not equal at the beginning. A comparison of the endpoint titers showed that there are not statistically significant differences. These results were in line with the findings of other researchers using similar epitopic or the fulllength of $\mathrm{F}$ or $\mathrm{HN}$ protein for immunogenicity in the animal models $(16,17,19)$. Furthermore, the detection of the $\mathrm{HN}$ and $\mathrm{F}$ glycoproteins with the individually produced antibodies revealed the potential application of these antibodies as probes for the viral glycoprotein in immunological analyses. The reactivity of the antiNDV serum toward the denatured recombinant $\mathrm{HN}$ and $\mathrm{F}$ proteins in ELISA opens the possible use of these recombinant proteins as antigens for diagnosis or vaccine survey of ND in poultry.

\section{Conclusions}

There are limited reports about the successful expression of NDV glycoproteins in E.coli as the host. In this investigation, using bioinformatics tools we miniaturized the structure of the $\mathrm{HN}$ and $\mathrm{F}$ with the appropriate design while keeping the immune properties of the recombinant glycoproteins under the defined conditions. Moreover, our finding has provided an outstanding information about the crossreactivity properties in addition to the biological activity of the synthetic recombinant proteins in comparison to the standard B1 strain of the NDV. These findings suggest the proper presentation of the antigens from recombinant glycoproteins to the animal immune system, which raises specific antibodies with the high affinity toward native proteins in NDV structure. Further investigations are needed to obtain better antibody titers in the mice serum or to generate potential immunogenicity in a chicken model which could be applicable as a practical approach for detection of NDV.

\section{Acknowledgements}

The National Institute of Genetic Engineering and Biotechnology financially supported this work (NIGEB grant number: 447).

\section{Conflicts of Interest}

The authors declare that they have no conflict of interest.

\section{References}

1. Miller PJ, Decanini EL, Afonso CL. Newcastle disease: evolution of genotypes and the related diagnostic challenges. Infect Genet Evol. 2010;10(1):26-35. doi: 10.1016/j.meegid.2009.09.012

2. Alexander DJ, Aldous EW, Fuller CM. The long view: a selective review of 40 years of Newcastle disease research. Avian Pathol. 2012;41(4):329-335. doi: 10.1080/03079457.2012.697991

3. Lim MAG. Newcastle Disease Vaccines. Commercial PlantProduced Recombinant Protein Products. 68. Berlin Heidelberg: Springer; 2014. p. 179-195.

4. Lamb RA, Jardetzky TS. Structural basis of viral invasion: lessons from paramyxovirus F. Curr Opin Struct Biol. 2007;17(4):427-436. doi: 10.1016/j.sbi.2007.08.016

5. Chen L, Gorman JJ, McKimm-Breschkin J, Lawrence LJ, Tulloch PA, Smith BJ, Colman PM, Lawrence MC. The structure of the fusion glycoprotein of Newcastle disease virus suggests a novel paradigm for the molecular mechanism of membrane fusion. Structure. 2001;9(3):255-266. doi: 10.1006/ viro.2001.1172

6. Takimoto T, Taylor GL, Connaris HC, Crennell SJ, Portner A. Role of the hemagglutinin-neuraminidase protein in the mechanism of paramyxovirus-cell membrane fusion. $J$ Virol. 2002;76(24):13028-13033. doi: 10.1128/JVI.76.24.1302813033.2002

7. Connolly SA, Leser GP, Jardetzky TS, Lamb RA. Bimolecular complementation of paramyxovirus fusion and hemagglutininneuraminidase proteins enhances fusion: implications for the mechanism of fusion triggering. J Virol. 2009;83(21):1085710868. doi: 10.1128/JVI.01191-09

8. Melanson VR, Iorio RM. Amino acid substitutions in the F-specific domain in the stalk of the Newcastle disease virus HN protein modulate fusion and interfere with its interaction with the F protein. J Virol. 2004;78(23):13053-13061. doi: 10.1128/JVI.78.23.13053-13061.2004

9. Toyoda T, Gotoh B, Sakaguchi T, Kida H, Nagai Y. Identification of amino acids relevant to three antigenic determinants on the fusion protein of Newcastle disease virus that are involved in fusion inhibition and neutralization. J Virol. 1988;62(11):44274430.

10. Iorio RM, Glickman RL, Sheehan JP. Inhibition of fusion by neutralizing monoclonal antibodies to the haemagglutininneuraminidase glycoprotein of Newcastle disease virus. $J$ Gen Virol. 1992;73(5):1167-1176. doi: 10.1099/0022-1317-73-51167

11. Hooper DC. Plant vaccines: an immunological perspective. Plant-produced Microbial Vaccines: Springer; 2009. p. 1-11. doi: 10.1007/978-3-540-70868-1_1

12. Perrie Y, Mohammed AR, Kirby DJ, McNeil SE, Bramwell VW. Vaccine adjuvant systems: enhancing the efficacy of sub- 
unit protein antigens. Int $J$ Pharm. 2008;364(2):272-80. doi: 10.1016/j.ijpharm.2008.04.036

13. De Groot AS, Berzofsky JA. From genome to vaccine-new immunoinformatics tools for vaccine design. Methods. 2004;34(4):425-428. doi: 10.1016/j.ymeth.2004.06.004

14. Berzofsky JA, Ahlers JD, Belyakov IM. Strategies for designing and optimizing new generation vaccines. Nat Rev Immunol. 2001;1(3):209-219. doi: 10.1038/35105075

15. World Organization for Animal Health (OIE). Newcastle disease: Manual of dignosis tests and vaccines for tresstrial animals. 6th ed. Paris, France 2012. p. 1-19.

16. Wong SK, Tan WS, Omar AR, Tan CS, Yusoff K. Immunogenic properties of recombinant ectodomain of Newcastle disease virus hemagglutinin-neuraminidase protein expressed in Escherichia coli. Acta Virol. 2009;53(1):35-41. doi:10:4149/ av_2009_01_35

17. Moon HJ, Park JE, Yoon H, Cruz DJM, Kim CJ, Shin HJ. Development of a novel recombinant heamagglutininneuramindase Elisa (rHN-ELISA) for evaluation of humoral immunity in chicken vaccinated against Newcastle disease virus (NDV). J. Anim. Vet. Adv. 2010;9(23):2932-2939. doi: 10.3923/javaa.2010.2932.2939

18. Frozandeh-Moghadam M, Madani R, Dehghani M, Mosavi $\mathrm{S}$, Pourbakhsh S, Golchinfar F. Cloning and expression of $\mathrm{F}$ protein gene (HR1 region) of Newcastle disease virus NR43 isolate from Iran in E. coli. Iran J Virol. 2009;3(3):16-22.

19. Shahid N, Tahir S, Rao AQ, Hassan S, Khan A, Latif A, Khan MA, Tabassum B, Shahid AA, Zafar AU. Escherichia coli expression of NDV fusion protein gene and determination of its antigenic epitopes. Biologia (Bratisl). 2015;70(12):1553-1564. doi: 10.1515/biolog-2015-0191

20. Schmidt F. Recombinant expression systems in the pharmaceutical industry. Appl Microbiol Biotechnol. 2004;65(4):363-372. doi: 10.1007/s00253-004-1656-9

21. Sadeghi M, Bandehpour M, Yarian F, Yassaee V, Torbati E, Kazemi B. Cloning and expression of influenza H1N1 NS1 protein in Escherichia Coli BL21. Iran J Biotechnol. 2014;12(1):25-29. doi: 10.5812/ijb.12625

22. Amorim JH, Porchia BF, Balan A, Cavalcante RC, da Costa SM, de Barcelos Alves AM, de Souza Ferreira LC. Refolded dengue virus type 2 NS1 protein expressed in Escherichia coli preserves structural and immunological properties of the native protein. J Virol Methods. 2010;167(2):186-192. doi: 10.1016/j. jviromet.2010.04.003

23. Zhou B, Liu K, Jiang Y, Wei J-C, Chen P-Y. Multiple linear B-cell epitopes of classical swine fever virus glycoprotein E2 expressed in E. coli as multiple epitope vaccine induces a protective immune response. Virol J. 2011;8(1):1-7. doi: 10.1186/1743-422X-8-378

24. Talha SM, Nemani SK, Salminen T, Kumar S, Swaminathan S, Soukka T, Pettersson K, Khanna N. Escherichia coli-expressed near full length HIV-1 envelope glycoprotein is a highly sensitive and specific diagnostic antigen. BMC Infect Dis. 2012;12(1):1-11. doi: 10.1186/1471-2334-12-325

25. Chen X, Zaro JL, Shen W-C. Fusion protein linkers: property, design and functionality. Adv Drug Delivery Rev. 2013;65(10):1357-1369. doi: 10.1016/j.addr.2012.09.039

26. Motamedi MJ, Amani J, Shahsavandi S, Salmanian AH. In Silico design of multimeric $\mathrm{HN}-\mathrm{F}$ antigen as a highly immunogenic peptide vaccine against Newcastle disease virus. Int J Peptide Res Therapeut. 2014;20(2):179-194. doi: 10.1007/s10989-0139380-x

27. Zoth SC, Gómez E, Carballeda JM, Carrillo E, Berinstein A. Expression of a secreted version of the hemagglutininneuraminidase glycoprotein of Newcastle disease virus Its evaluation as a diagnostic reagent. J Vet Diagn Invest. 2011;23(3):519-523. doi: 10.1177/1040638711404153

28. Loke C, Omar AR, Raha A, Yusoff K. Improved protection from velogenic Newcastle disease virus challenge following multiple immunizations with plasmid DNA encoding for $\mathrm{F}$ and $\mathrm{HN}$ genes. Vet Immunol Immunopathol. 2005;106(3):259-267. doi: 10.1016/j.vetimm.2005.03.005

29. Lai KS, Yusoff K, Mahmood M. Functional ectodomain of the hemagglutinin-neuraminidase protein is expressed in transgenic tobacco cells as a candidate vaccine against Newcastle disease virus. Plant Cell Tiss Org. 2013;112(1):117-121. doi: 10.1007/ s11240-012-0214-x

30. Bukreyev A, Skiadopoulos MH, Murphy BR, Collins PL. Nonsegmented negative-strand viruses as vaccine vectors. $J$ Virol. 2006;80(21):10293-10306. doi: 10.1128/JVI.00919-06

31. Yusoff K, Tan WS. Newcastle disease virus: macromolecules and opportunities. Avian Pathol. 2001;30(5):439-455. doi: 10.1080/03079450120078626

32. Hwang PM, Pan JS, Sykes BD. Targeted expression, purification, and cleavage of fusion proteins from inclusion bodies in Escherichia coli. FEBS Lett. 2014;588(2):247-252. doi: 10.1016/j.febslet.2013.09.028

33. Sørensen HP, Mortensen KK. Soluble expression of recombinant proteins in the cytoplasm of Escherichia coli. Microb Cell Fact. 2005;4(1):1-8. doi: 10.1186/1475-2859-4-1

34. Yamaguchi H, Miyazaki M. Refolding techniques for recovering biologically active recombinant proteins from inclusion bodies. Biomolecules. 2014;4(1):235-251. doi: 10.3390/biom4010235

35. Sun HL, Wang YF, Tong GZ, Zhang PJ, Miao DY, Zhi HD, Wang M, Wang M. Protection of chickens from Newcastle disease and infectious laryngotracheitis with a recombinant fowlpox virus co-expressing the F, HN genes of Newcastle disease virus and $\mathrm{gB}$ gene of infectious laryngotracheitis virus. Avian Dis. 2008;52(1):111-117. doi: 10.1637/7998-041807-Reg

36. Iorio RM, Glickman RL, Riel AM, Sheehan JP, Bratt MA. Functional and neutralization profile of seven overlapping antigenic sites on the HN glycoprotein of Newcastle disease virus: monoclonal antibodies to some sites prevent viral attachment. Virus Res. 1989;13(3):245-261. doi: 10.1016/01681702(89)90019-1

37. Yusoff K, Nesbit M, McCartney H, Meulemans G, Alexander D, Collins M, Emmerson PT, Samson ACR. Location of neutralizing epitopes on the fusion protein of Newcastle disease virus strain Beaudette C. J Gen Virol. 1989;70(11):3105-3109. doi: 10.1099/0022-1317-70-11-3105

38. Zhou Y-H, Chen Z, Purcell RH, Emerson SU. Positive reactions on Western blots do not necessarily indicate the epitopes on antigens are continuous. Immunol Cell Biol. 2007;85(1):73-78. doi: 10.1038/sj.icb.7100004

39. Long L, Portetelle D, Ghysdael J, Gonze M, Burny A, Meulemans G. Monoclonal antibodies to hemagglutinin- 


\section{Motamedi MJ et al.}

neuraminidase and fusion glycoproteins of Newcastle disease virus: relationship between glycosylation and reactivity. $J$ Virol. 1986;57(3):1198-1202.

40. Chambers P, Nesbit M, Yusoff K, Millar N, Samson A, Emmerson P. Location of a neutralizing epitope for the haemagglutininneuraminidase glycoprotein of Newcastle disease virus. $J$ Gen Virol. 1988;69(8):2115-2122.

41. Panshin A, Shihmanter E, Weisman Y, Örvell C, Lipkind M. Variability of antigenic epitopes of the fusion protein of Newcastle disease virus. Comp Immunol Microbiol Infect Dis. 1998;21(1):51-63. doi: 10.1016/S0147-9571(97)00016-7
42. Yin L, Chen X, Tiwari A, Vicini P, Hickling TP. The role of aggregates of therapeutic protein products in immunogenicity: an evaluation by mathematical modeling. J Immunol Res. 2015;2015: 1-14. doi: 10.1155/2015/401956

43. Silva KR, Goncalves MCM, de Oliveira ES, Fernando FS, Montassier MdFS, Fernandes CC, Tamanine MdLF, Borzi MM, dos Santos RM, de Oliveira Mendonca, A. Cloning and expression of the nucleoprotein gene (NP) of Newcastle disease virus (NDV) in Escherichia coli for immunodiagnosis application. Int J Poultry Sci. 2014;13(8):473-479. doi: 10.3923/ ijps.2014.473.479 